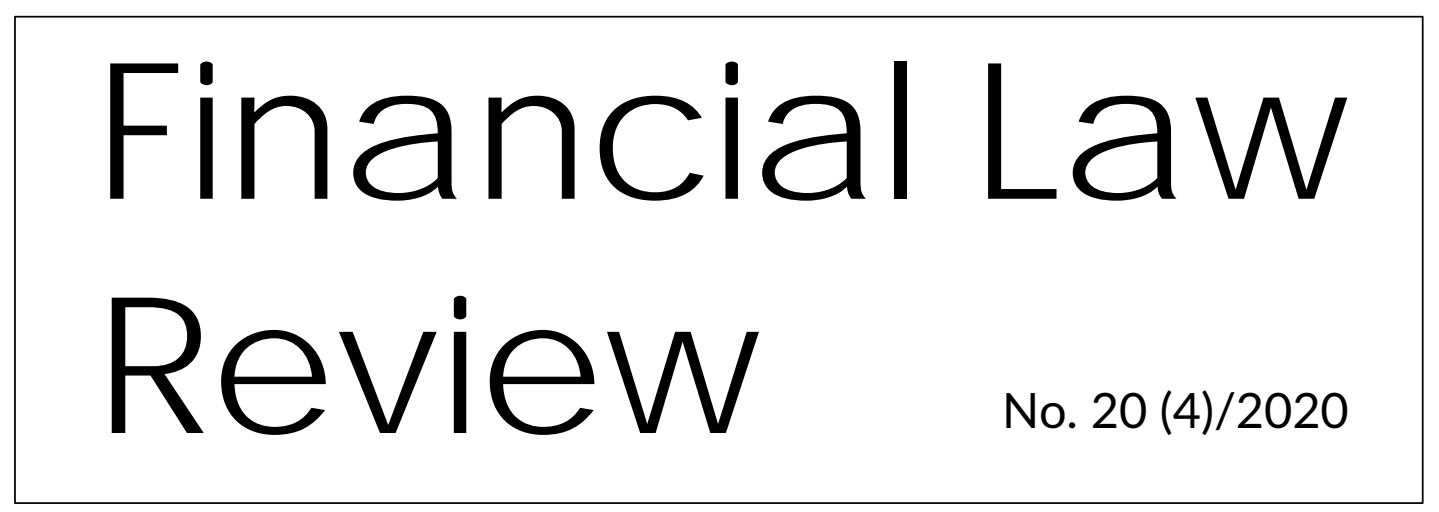

UNIVERSITY OF GDAŃSK • MASARYK UNIVERSITY • PAVEL JOZEF ŠAFÁRIK UNIVERSITY • UNIVERSITY OF VORONEZH http://www.ejoumals.eu/FLR

\title{
OWN RESOURCES IN THE LIGHT OF EUROPEAN COUNCIL CONCLUSIONS ON THE MFF AND NEXT GENERATION EU
}

\begin{abstract}
The article deals with the system of EU own resources which is currently formed by traditional own resources, VAT-based resource and GNI-based resource. The system and its potential reform have been subject of scientific and political debates for many years. On 21 July 2020, the European Council agreed on the multiannual financial framework 2021-2027 and a specific recovery instrument Next Generation EU. The European Council conclusions also confirmed the need to reform the existing system and to introduce new own resources (e.g. resource based on nonrecycled plastic waste). Therefore, this article aims to elaborate on the EU own resources and their future post-2020. The methods of description, analysis, comparison, and synthesis were used for writing this contribution. First, the current system of EU budget revenue is analysed. Second, reform efforts since the establishment of the High Level Group on Own Resources are described. Third, the European Commission's original proposal from 2018 is compared to the European Council conclusions.
\end{abstract}

Key words: budget, European Union, GNI, multiannual financial framework, Next Generation EU, own resources, plastic waste, VAT.

JEL Classification: F36, H27, K33

* Ph.D. student at the Department of Financial Law and Economics, Faculty of Law, Masaryk University in Brno, Czech Republic. Author specializes in EU funding and regional policy. Contact email: romana.buzkova@law.muni.cz. 


\section{Introduction}

This article deals with the own resources of the European Union and their future post2020. The European Council and the Council of the European Union play a central role in a) the process of establishing the EU long-term budget; b) defining where the revenue comes from [Negotiating the EU long-term budget]. The current system of EU own resources primarily rests on national contributions with various correction mechanisms, which brings tensions between net contributors and net beneficiaries [Hudetz et al. 2017: 609-613]. In addition, the system does not reflect or directly supports core EU policies [Schratzenstaller 2013: 303-313]. The idea of reform is not new in the literature, nor in the work of EU institutions [Benedetto 2017: 615-633]. Also, those who oppose more financial autonomy for the European Union generally agree that the opaque and complex system should be streamlined. However, the need for reform does not necessarily translate into the ability to reform due to the decision-making process, which in case of own resources requires unanimity [D'Alfonso 2016: 46-83].

Negotiations usually kick off a few years before the start of a new period. The European Commission presented a legislative package regarding the multiannual financial framework (MFF) for the period 2021-2027 and new own resources in May 2018 [COM (2018) 321 final]. Since then, the interinstitutional negotiations have been ongoing. In December 2019, the newly appointed European Commission announced its growth strategy called the European Green Deal [COM (2019) 640 final]. Committed to tackle climate change and support economic transformation, the Commission published a proposal for Just Transition Mechanism, including a proposal for establishing the Just Transition Fund, coming on top of existing MFF proposals [COM (2020) 22 final]. However, the outbreak of coronavirus pandemic with massive socio-economic impact have complicated the negotiations. New priorities have emerged. As a result, the Commission presented its recovery plan in May 2020 [COM (2020) 442 final]. The package is based on three pillars: amended MFF 20212027, amended own resources proposal and Next Generation EU (European Union Recovery Instrument for the years 2021-2024). Although they have different legal bases (and their adoption is subject to different procedures; see below), the European Council's meeting held in July 2020 finally brought an agreement among EU leaders. This agreement is paving the way for the Commission, the European Parliament and the Council to proceed. Existing own resources system shall be reformed and new resources introduced.

Therefore, this article aims to elaborate on the current situation of EU budget revenue and reforms of the own resources system in the light of the latest European Council 
conclusions. The methods of description, analysis, comparison, and synthesis were used for writing this contribution. First, the current system of EU budget revenue is analysed. Second, reform efforts since the establishment of the High Level Group on Own Resources are described. Third, the European Commission's original proposal on the multiannual financial framework 2021-2027 is compared to the European Council conclusions.

\section{Legal basis}

The EU budget serves as a financial plan which comprises all the revenue and expenditure of the European Union. The concept of the general budget also refers to a legally binding act that has to be adopted according to the ordinary budgetary procedure. Every annual budget must be established within the multiannual financial framework and is governed by a number of budgetary principles deriving from the provisions of the Treaty on the Functioning of the European Union [Kosikowski 2008: 120-123].

The multiannual financial framework ensures that the EU expenditure develops within the limits of own resources in an orderly manner. It is adopted by the Council of the European Union under a special legislative procedure [TFEU, Article 312]. Table 1 shows the complexity of MFF and own resources negotiations.

Table 1. Adoption of legal acts concerning the EU long-term budget.

\begin{tabular}{|c|c|c|c|c|}
\hline Adoption of & Legal act & $\begin{array}{c}\text { Legislative } \\
\text { procedure }\end{array}$ & EP's role & Legal basis \\
\hline MFF & $\begin{array}{c}\text { Council } \\
\text { Regulation }\end{array}$ & $\begin{array}{c}\text { Special } \\
\text { (unanimity) }\end{array}$ & $\begin{array}{c}\text { Consent } \\
\text { (majority) }\end{array}$ & $\begin{array}{c}\text { Article 312 } \\
\text { TFEU }\end{array}$ \\
\hline $\begin{array}{c}\text { Own } \\
\text { resources }\end{array}$ & $\begin{array}{c}\text { Council } \\
\text { Decision }\end{array}$ & $\begin{array}{c}\text { Special } \\
\text { (unanimity) }\end{array}$ & Consultation & $\begin{array}{c}\text { Article 311 } \\
\text { TFEU }\end{array}$ \\
\hline
\end{tabular}

Source: author's own elaboration.

The legal basis for EU budget revenue is laid down in Articles 310 and 311 TFEU. Without prejudice to other revenue, the EU budget shall be financed wholly from own resources. Under a special legislative procedure, the Council of the European Union unanimously adopts a decision laying down the provisions relating to the system of own resources. The European Parliament has a consultative role in that case. Such decision shall not enter into force until it is approved by the Member States in accordance with their respective constitutional requirements. The procedure that applies to the own resources system, 
which requires unanimity in the Council and ratification by all Member States, make veto threats extremely credible [D'Alfonso 2016: 46-83].

The current form of revenue was specified in 2014 and comprised three main categories of resources [Council Decision 2014/335 (EU, Euratom)]. This area is further regulated by other acts, for instance, Council Regulation 609/2014 on the methods and procedure for making these resources available and on the measures to meet cash requirements or Council Regulation 608/2014 laying down implementing measures for the EU own resources system.

\section{Current system of own resources}

The system and collection of EU own resources reflect the financial autonomy of the European Union. Any failures in transferring funds caused by the Member States are recognised as failures to fulfil the obligation under the Treaties [Tyniewicki 2008: 31]. The system is formed by three main groups of resources:

a) Traditional own resources; (levies, premiums, additional or compensatory amounts, customs duties, contributions and other duties regarding markets in sugar)

Traditional own resources cover the customs duties (including agricultural levies) that are imposed on third countries' products and are collected at the external borders of the single market. The Member States retain 20\% of the collected amounts as collection costs, whereas the rest is forwarded straight to the EU budget [Council Decision 2014/335 (EU, Euratom), Article 2].

b) Value Added Tax-based resource;

The VAT is paid by all Member States and calculated by applying a uniform rate of $0,30 \%$ to the harmonised tax base (which shall not exceed $50 \%$ of the gross national income for each Member State). For the period 2014-2020, Germany, the Netherlands and Sweden benefit from a reduced rate that is fixed at 0,15\% [Council Decision 2014/335 (EU, Euratom), Article 2].

\section{c) Gross National Income-based resource.}

Each Member State is obliged to transfer a standard percentage of its Gross National Income to the EU budget, although, there are corrections to reduce excessive contributions by the certain Member States. For the period 2014-2020, Denmark, the Netherlands and Sweden benefit from gross reductions in their annual GNI contribution of 130 million, 695 million and 185 million EUR. Austria benefited from reductions in 2014- 
2016 only. The total amount that may be collected from the Member States in any given year is limited; the own resources ceiling is recalculated based on a formula set out in Article 3 of the Council Decision. Currently, the ceiling is at 1,20\% of the sum of all the Member States' GNIs [Gross National Income-based own resource].

However, only the traditional own resources listed under letter a) can qualify as "true" own resources since the Value Added Tax-based resource and Gross National Income-based resource are national contributions. The revenue deriving from other sources can be formed by any surplus available from the preceding financial year, borrowing and lending activities, revenue from administrative operations or taxes on EU employees' salaries [Kosikowski 2008: 78]. The following graph shows the evolution of EU budget revenue sources and the share of traditional own resources, VAT-based resource and GNI-based resource in 2018 when the Commission presented its legislative package for post-2020. The GNI-based contributions massively prevail, followed by traditional own resources and VAT-based resource.

\section{Graph 1. Evolution of the EU revenue sources}

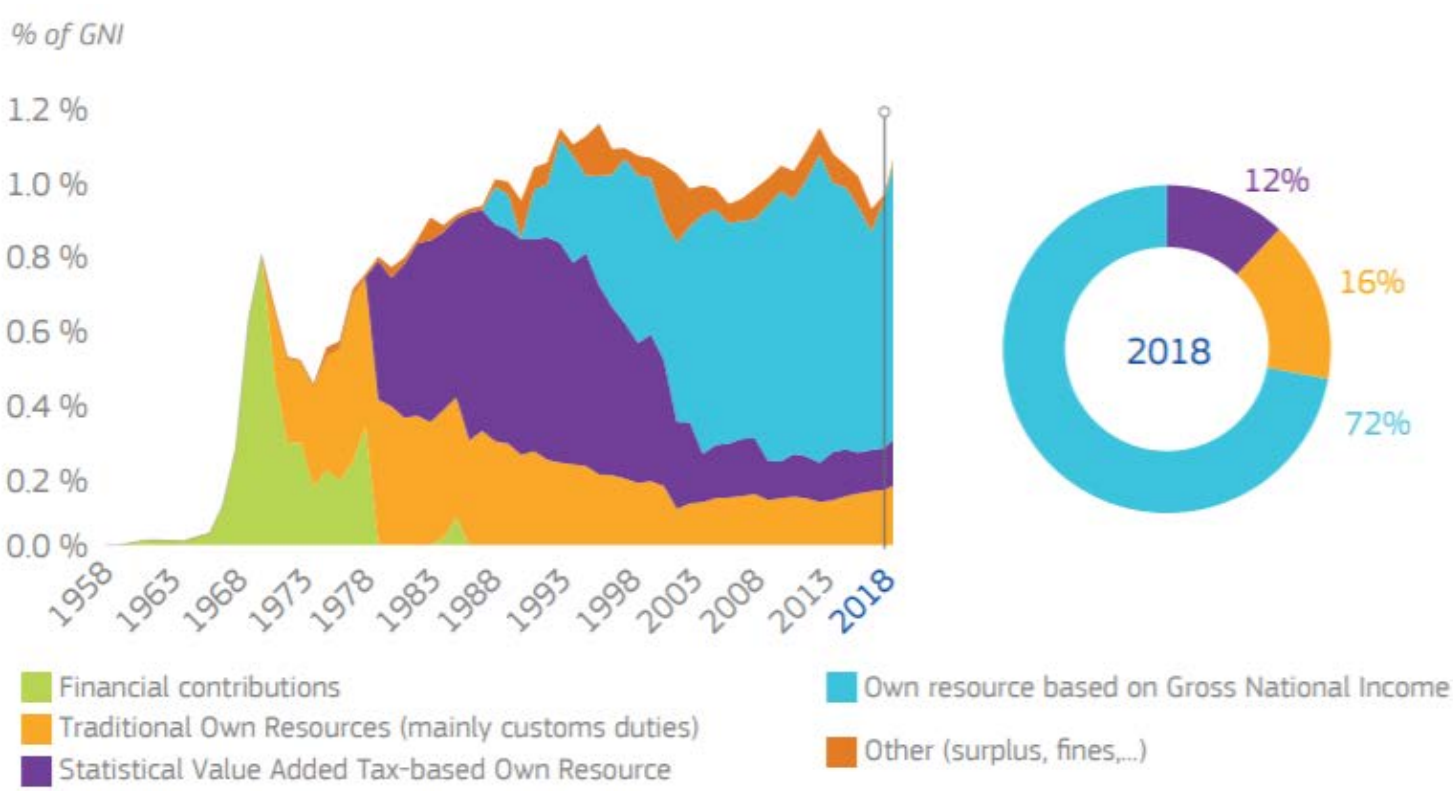

Source: European Commission. Modernising the EU budget's revenue side, 2018.

\section{Reform efforts}

The financing system of the European Union has remained unchanged since 1988. If we look at the revenue side, the Gross National Income-based resource dominates. There are many tax instruments that could potentially be mobilised to either replace or complement 
current own resources, but there is no single optimal solution. A reform based solely on new tax-based mechanisms is unlikely to go forward as it does not address the remaining concerns about policy quality [Núñez Ferrer et al. 2016: 15-17]. In the past, the European Council conclusions regarding the multiannual financial framework 2014-2020 explicitly mentioned the financial transaction tax-based resource; the Member States cooperating in this area were invited to examine if it could become the base for a new own resource [EUCO 37/13], but negotiations on the financial transaction tax proved to be complicated.

The High Level Group on Own Resources (with Chairman Mario Monti) was established in 2014 to explore how the revenue side of the EU budget could be more simple, transparent, fair and democratically accountable. In its final report from December 2016, the Group analysed existing resources, examined which should be maintained and prepared a list of potential new own resources. Based on the report and recommendations, the European Commission has assessed whether reform is appropriate. The Reflection Paper on the Future of EU Finances published in 2017 confirmed the need to reform the EU budget.

In order to analyse and evaluate the effectiveness of each resource, they must be assessed according to some criteria. For example, König [2009] uses three groups: economic, administrative and political criteria; Tyniewicki [2008] uses financial, economic and legal criteria. Concerning the degree of sustainability, it is possible to distinguish ecological, economic, socio-cultural and administrative criteria [Cieslukowski, 2016]. The High Level Group worked with the below-mentioned set of various criteria to assess and compare different types of resources. All examined revenue sources were given a score in each of these categories [Final report and recommendations of the High Level Group on Own Resources, 87-94]:

- Equity/Fairness;

- Efficiency;

- Sufficiency \& Stability;

- Transparency \& Simplicity;

- Democratic accountability \& budgetary discipline;

- Focus on European added value;

- Subsidiarity principle;

- Limit political transaction costs.

The High Level Group presented several candidates for new own resources that were communicated to the institutions and the public. Besides a reformed VAT-based resource, the options contained the following: 
- Carbon tax-based resource;

- Inclusion of the EU Emissions Trading Scheme (ETS) proceeds;

- Motor fuel levy;

- Electricity tax-based resource;

- EU corporate income tax (CСCTB);

- Financial transaction tax (FTT) or as an alternative option bank levy;

- Seigniorage.

If we take a closer look at tax-based own resources, they have to comply with limited tax competences of the EU (Articles 113 and 115 TFEU in case of harmonisation or approximation, Articles 192 and 194 TFEU in case of fiscal measures pursuing environmental and energy purposes). According to Schratzenstaller and Krenek [2019], there are various design options for new tax-based own resources: revenue sharing system, surcharge system or separation system. Unlike the separation system, which would require own legislative and revenue competences of the Union, the first two systems are compatible with the Treaties.

\section{Original MFF proposal versus European Council conclusions}

On 2 May 2018, the European Commission published a proposal for the EU long-term budget, the multiannual financial framework 2021-2027, which also counts with a reformed set of own resources that would generate additional income after Brexit [COM (2018) 322 final]. Together with the MFF proposal, the Commission also proposed a legislative package for the reform of the Union's own resources system, including a proposal for a new Council Decision on the system of own resources of the European Union [COM (2018) 325 final] and implementing measures. The proposed decision maintains and reforms the existing resources (traditional own resources, a modified version of the Value Added Tax-based resource and the Gross National Income-based resource). According to this proposal, the collection costs should be reduced to $10 \%$, VAT-based resource simplified, own resources ceiling increased, and corrections phased out through a transition mechanism. Besides, the proposal introduces a basket of three new own resources. Thanks to them, the overall share of GNI-based resource would be smaller (from almost $72 \%$ in 2018 to estimated average 58\% in 2021-2027). The proposed new own resources are based on the: 
- Common Consolidated Tax Base;

Corporate taxation is aimed at multinational companies operating in the single market and should help the EU efforts to tackle tax avoidance. This resource is supposed to be calculated each year by each Member State by applying a uniform call rate of $3 \%$ to the share of taxable profits attributed to that Member State under the rules on CCCTB [Proposal COM (2018) 326 final].

- European Union Emissions Trading System;

The European Union has created its common instrument to fight climate change. The Emissions Trading System is harmonised at the Union level, and revenues flow to national budgets. By allocating $20 \%$ of certain revenues from the total number of allowances available for auction to the EU budget, this resource could bring up to 3 billion EUR each year [Proposal COM (2018) 325 final)].

- Plastic packaging waste that is not recycled.

This resource would be directly proportional to the quantity of non-recycled plastic packaging waste generated in each Member State. Member States' contributions would be calculated by applying a call rate of $0,80 \mathrm{EUR} / \mathrm{kg}$ to this quantity. The contributions could provide an incentive for the Member States to reduce their waste streams [Proposal COM (2018) 325 final].

The debates in the Council of the European Union focused mainly on plastic packaging waste-based resource. Some delegates of the Council proposed to explore also different options (such as FTT or digital tax) while the majority of delegates expressed their preference for discarding the Common Consolidated Corporate Tax Base as new own resource [Progress report 9911/19]. In October 2019, the newly elected European Parliament adopted a resolution on the MFF and own resources. It reaffirmed its position on the list of potential new resources ${ }^{1}$, namely the Common Consolidated Corporate Tax Base, digital services taxation, financial transaction tax, income from the EU Emissions Trading Scheme, plastics contribution and a carbon border adjustment mechanism. The Parliament also agrees with the abolition of corrections, VAT-based resource simplification, reduction of collection costs and the inclusion of fines and fees in the EU budget [2019/2833 (RSP)].

\footnotetext{
${ }^{1}$ Some of them had not been included in the original Commission's proposal.
} 
A special European Council's meeting held in February 2020 brought no agreement on the next multiannual financial framework. However, the European Commission amended proposals from 28 May 2020 and European Council conclusions from 21 July 2020 radically changed the scene. The MFF 2021-2027 will be worth 1074,3 billion EUR. For the first time in the history of the EU, the Commission will be authorised to borrow funds on the capital markets (up to additional 750 billion EUR), but borrowed funds can be used solely for addressing the consequences of COVID-19 pandemic. For the purpose of covering these liabilities, the own resources ceiling shall be temporarily increased by 0,6 percentage points. On a permanent basis, the own resources ceiling shall be increased to $1.46 \%$ of EU GNI for commitments and to $1.40 \%$ for payments. The conclusions further count with the establishment of new own resources which will be used for early repayment of the Next Generation EU borrowings. The own resources system should be reformed in the following way [EUCO 10/20].

\section{a) Traditional own resources;}

From 1 January 2021, the Member States shall retain 25\% of the collected amounts as collection costs which is $5 \%$ more than nowadays and $15 \%$ more than what the Commission proposed two years ago.

b) Value Added Tax-based resource;

From January 2019, the VAT-based resource should be replaced by a simplified and refined alternative method; a rate of $0,30 \%$ will be applied to VAT bases of the Member States which shall not exceed $50 \%$ of their gross national income.

c) Gross National Income-based resource;

The method will remain unchanged. For the period 2021-2027, Denmark, Germany, the Netherlands, Sweden and Austria will benefit from corrections. Unlike the original proposal, European Council conclusions do not count with a transition mechanism to phase them out. However, the Commission still operates with this possibility in the future

\section{d) New own resources.}

Firstly, a new own resource based on non-recycled plastic packaging waste will be introduced from 1 January 2021. The Member States' contributions will be calculated by applying a call rate of $0,80 \mathrm{EUR} / \mathrm{kg}$ to the waste quantity. In this way, the EU budget would help to meet the EU objectives for circular economy and strategy for plastics. However, the so-called "plastic tax" is criticised by the plastic industry, which warns that it might have the opposite effect on resource efficiency and jeopardise the competitiveness of an 
entire industry [Press releases of European Plastic Converters and PlasticsEurope]. Secondly, proposals for a carbon border adjustment mechanism and a digital levy should be put forward (and introduced at the latest by 1 January 2023), followed by proposals to revise the Emissions Trading Scheme (with possible extension to maritime and aviation) and to introduce other resources which may include financial transaction tax. All elements of the new EU own resources system should apply retroactively from 1 January 2021. The new system will enter into force on the first day of the first month following receipt of the notification of the completion of the procedures for its adoption by the last Member State [Annex to EUCO 10/20].

The legislative work still has to be finalised. The MFF regulation is adopted under a special legislative procedure; the Council acts unanimously after obtaining consent from the European Parliament [TFEU, Article 312]. The own resources decision, as previously mentioned, is also adopted under a special legislative procedure, but the role of the European Parliament is consultative. Implementing measures for the own resources system are laid down by the Council after receiving the European Parliament's consent [TFEU, Article 311].

Draft Council Decision 10025/20 on the system of own resources from 29 July 2020 reflects the above mentioned European Council conclusions. The new own resource based on plastic packaging waste that is not recycled should be introduced as the first step. In order to avoid excessive impact on national contributions, an adjustment mechanism should apply to the Member States with GNIs per capita below the EU average. For instance, the Czech Republic shall be entitled to an annual lump sum reduction of 32 million EUR.

\section{Conclusion}

This article elaborated on the current system of EU own resources which is formed by traditional own resources, Value Added Tax-based resource and Gross National Incomebased resource. Regarding the reform efforts, special attention was paid to the proposals for a Council Regulation laying down the multiannual financial framework 2021-2027 and a Council Decision on the system of own resources. The European Commission's 2018 proposal originally counted with three new categories of own resources based on the Common Consolidated Corporate Tax Base, EU Emissions Trading Scheme and plastic packaging waste that is not recycled. Any Council decision establishing or abolishing 
categories of own resources must be unanimously adopted in accordance with a special legislative procedure. The European Parliament's role is only consultative. Although the Commission and the European Parliament repeatedly expressed their position on the introduction of new own resources, there was no agreement among EU leaders until the European Council's meeting, which was held in July 2020.

The article summarised the key moments of interinstitutional negotiations. A political consensus was reached on the MFF post-2020 and the recovery instrument Next Generation EU which aims to tackle the negative effects of the crisis. The European Council conclusions count with a reformed own resources system and the introduction of new sources of revenue which would be used for early repayment of the Next Generation EU borrowing. The first new own resource, applicable from 1 January 2021, should be based on non-recycled plastic packaging waste in the Member States. The Commission's proposals on a carbon border adjustment mechanism, digital levy, Emissions Trading Scheme and eventually financial transaction tax should follow. The relevant legislative texts should be adopted as soon as possible in order to avoid further delays. 


\section{References}

Benedetto, G.: Institutions and the route to reform of the European Union's budget revenue, 19702017, Empirica, Vol. 44, Issue 4, 2017.

Cieslukowski, M.: A Sustainable European Union Own Resources System, Perspectives on Federalism, Vol. 8, Issue 2, 2016.

D'Alfonso, A.: Reforming the financing of the EU budget: Outlook, Perspectives on Federalism, Vol. 8, Issue 2, 2016.

Hudetz, A. et al.: Reform needs and options in the EU system of own resources, Empirica, Vol. 44, Issue 4, 2017.

König, P. et al.: Rozpočet a politiky Evropské unie. Přiležitost pro změnu [The budget and policies of the European Union. Opportunity for a change], Praha: C. H. Beck, 2009.

Kosikowski, C.: Financial Law of the European Union, Białystok: Temida 2, 2008.

Núñez Ferrer, J. et al.: Study on the Potential and Limitations of Reforming the Financing of the EU Budget, Brussels: Centre for European Policy Studies, 2016.

Schratzenstaller, M.: The EU Own Resources System - Reform Needs and Options, Intereconomics, Vol. 48, Issue 5, 2013.

Schratzenstaller, M., Krenek, A.: Tax-based Own Resources to Finance the EU Budget, Intereconomics, Vol. 54, Issue 3, 2019.

Tyniewicki, M.: General Budget and Budget Law of the European Union. Białystok: Temida 2, 2008.

\section{Legal Acts}

Consolidated version of the Treaty on the Functioning of the European Union.

Council Decision 2014/335 (EU, Euratom) of 26 May 2014 on the system of own resources of the European Union.

Council Regulation 608/2014 (EU, Euratom) of 26 May 2014 laying down implementing measures for the system of own resources of the European Union.

Council Regulation 609/2014 (EU, Euratom) of 26 May 2014 on the methods and procedure for making available the traditional, VAT and GNI-based own resources and on the measures to meet cash requirements.

Draft Council Decision 10025/20 (EU, Euratom) on the system of own resources of the European Union.

European Council conclusions EUCO 10/20 of 17, 18, 19, 20 and 21 July 2020.

European Council conclusions EUCO 37/13 of 7 and 8 February 2013.

European Parliament resolution 2019/2833 (RSP) on the 2021-2027 multiannual financial framework and own resources: time to meet citizens' expectations.

Proposal COM (2018) 322 final for a Council Regulation laying down the multiannual financial framework for the years 2021 to 2027.

Proposal COM (2018) 325 final for a Council Decision on the system of Own Resources of the European Union.

Proposal COM (2018) 326 final for a Council Regulation on the methods and procedure for making available the Own Resources.

Proposal COM (2020) 22 final for a Regulation of the European Parliament and of the Council establishing the Just Transition Fund.

\section{Other official documents}

Communication COM (2018) 321 final. A Modern Budget for a Union that Protects, Empowers and Defends. The Multiannual Financial Framework for 2021-2027. Available at: https://eurlex.europa.eu/legal-content/EN/TXT/?uri=COM:2018:321:FIN

Communication COM (2019) 640 final. The European Green Deal. Available at: https://eurlex.europa.eu/legal-content/EN/TXT/?uri=COM:2019:640:FIN

Communication COM (2020) 442 final. The EU budget powering the recovery plan for Europe. Available at: https://eur-lex.europa.eu/legal-content/EN/TXT/?uri=COM:2020:442:FIN

European Commission. Reflection Paper on the Future of EU Finances. Available at: https://ec.europa.eu/commission/sites/beta-political/files/reflection-paper-eufinances en.pdf 
Council of the European Union. MFF 2021-27: Own Resources legislative package -Progress report 9911/19. Available at: https://data.consilium.europa.eu/doc/document/ST-9911-2019INIT/en/pdf

Final report and recommendations of the High Level Group on Own Resources. Available at: http://ec.europa.eu/budget/mff/hlgor/library/reports-communication/hlgorreport 20170104.pdf

\section{Internet Resources}

European Commission. Gross National Income-based own resource. Available at: https://ec.europa.eu/info/strategy/eu-budget/revenue/own-resources/nationalcontributions en, accessed: $30^{\text {th }}$ August 2020.

European Commission. Modernising the EU budget's revenue side. Available at: https://ec.europa.eu/commission/sites/beta-political/files/budget-proposals-modernisingbudget-revenue-side-may2018 en.pdf, accessed 18 ${ }^{\text {th }}$ September 2020.

European Council. Negotiating the EU long-term budget. Available at: https://www.consilium.europa.eu/en/policies/the-eu-budget/negotiating-the-long-term-eubudget/, accessed $18^{\text {th }}$ September 2020.

European Plastic Converters. EU Plastic Tax approved by European Council: A Danger for the EU Single Market \& Recovery. Available at: https://www.plasticsconverters.eu/post/eu-plastictax-approved-by-european-council-a-danger-for-the-eu-single-market-recovery, accessed: $31^{\text {st }}$ August 2020.

PlasticsEurope. Resource efficiency at risk: A plastic tax could jeopardize the circular economy goals. Available at: https://www.plasticseurope.org/en/newsroom/press-releases/archivepress-releases-2018/resource-efficiency-risk-plastic-tax-could-jeopardize-circular-economygoals, accessed: 31 ${ }^{\text {st }}$ August 2020. 